dr Miloš D. Đurić*

Elektrotehnički fakultet

Univerzitet u Beogradu

prof. dr Nada Krnjaić-Cekić

Mašinski fakultet

Univerzitet u Beogradu

\title{
TRI DECENIJE TEORIJE RELEVANTNOSTI I PREVOĐENJE NAUČNOG REGISTRA ZASNOVANO NA TEORIJI RELEVANTNOSTI
}

\section{Sažetak}

Naš rad istražuje primenu teorije relevantnosti na prevođenje naučnog registra. Ovaj registar obuhvata usmene i pismene podatke koje pripadaju diskursu elektrotehnike, računarstva i mašinstva. Prvi deo daje uvodna razmatranja o teoriji relevantnosti. Drugi deo je deskriptivno istraživanje tri decenije teorije relevantnosti zasnovano na pertinentnoj lingvističkoj literaturi. U fokusu trećeg dela rada nalaze se teorija relevantnosti i prevođenje konkretnog jezičkog materijala sakupljenog iz prevodilačke prakse autora. Primerima iz korpusa ilustrovani su izvesni slučajevi leksičko-pragmatičkih procesa, kada prevodilice pokušavaju da premoste jaz između jezičkog materijala koji je jezički kodiran i onoga što se zapravo saopštava u izvornom jezičkom materijalu. U četvrtom delu rada iznosimo zaključne napomene.

Ključne reči: Teorija relevantnosti, naučni registar, prevodni ekvivalenti, diskurs elektrotehnike, računarstva i mašinstva, leksičko-pragmatički procesi.

\section{Teorija relevantnosti: uvodna razmatranja}

Prema literaturi, teorija relevantnosti se određuje kao teorija pragmatike koju su razvijali Sperber i Vilsonova osamdesetih godina XX veka.

Elektrotehnički fakultet, Bulevar kralja Aleksandra 73, Beograd

MilosDDjuric@hotmail.com 
Na dalje, u literaturi se navodi da se ova teorija često posmatra kao konsolidacija Grajsove teorije konverzacijskih maksima, ali se razlikuje uvođenjem stručnog termina „relevantnost“, a koja se definiše kao svojstvo koje bilo koji iskaz, ili propozicija koju ovaj iskaz saopštava, mora, u prirodi komunikacije, neophodno imati (Matthews 2005: 317).

Prema relevantnoj literaturi, „tokom proteklih tridesetak godina, pragmatika se razvila u disciplinu sa sigurnim institucionalnim temeljima“ (Žegarac 2005: 3). Isti autor konstatuje da je i pored ovih institucionalnih dostignuća pragmatika ostala nesigurna naučna disciplina (Žegarac 2005: 3). Postoje brojna pitanja na koje bi pragmatika trebalo da pruži eksplicitne odgovore. Upravo je, prema literaturi, teorija relevantnosti probudila interesovanje mnogih pragmatičara i lingvista time što je postavila pitanja koja podstiču na razmišljanje u vezi sa mnogim intrigantnim problemima (Padilla Cruz 2016: 1). Isto tako, smatra se i da je teorija relevantnosti „[...] najambiciozniji, i verovatno do danas najuspešniji, pokušaj da se [...]“" (Žegarac 2005: 3) odgovori na najznačajnija pitanja u pragmatici i da se ispune zahtevi u vidu. Prema literaturi, u međuvremenu, delovanje u okviru teorije relevantnosti postalo je kolektivni poduhvat (Sperber \& Wilson 1998: v).

U literaturi se, s pravom, iznosi konstatacija da ,[...] značenje ne može sveobuhvatno „dosegnuti“ semantika [...] a da joj se ne pridruži u tom proučavanju i pragmatika [...]“" (Kordić 1991: 87). Prema literaturi, teorija relevantnosti je nastala kao uzbudljiv napor da se iznađu ubedljivi odgovori na niz samo naizgled jednostavnih i očiglednih pitanja za koje je većina pragmatičara mislila da su pronašli konačne odgovore (Padilla Cruz 2016: 3).

Kada daju istorijski pregled razvoja teorije relevantnosti i upotrebe termina „relevantan“ u lingvistici, pojedini autori naglašavaju da je tokom sedamdesetih godina XX veka postojalo malo interesovanje za pojam relevantnosti, zato što su istraživači smatrali da nijedan pokušaj primene ovog pojma na formalne semantičke teorije nije bio dovoljno uspešan da bi se koristio u pragmatici (Yus Ramos 1998: 306;). Autori se uglavnom slažu da je izuzetak bila Daskalova analiza (Dascal 1977) pojma relevantnosti u dvostrukoj semantičkoj/pragmatičkoj relevantnosti (Yus Ramos 1998: 306). Pojedini autori čak govore i o revoluciji zasnovanoj na teoriji relevantnosti (npr. Padill Cruz 2016: 3).

$\mathrm{U}$ literaturi se explicite navodi da je teorija relevantnosti inferencijalni pristup pragmatici (Wilson \& Sperber 2002: 45). Upravo je inferen- 
cijalni model komunikacije prva ozbiljnija alternativa klasičnom kodnom modelu (Wilson \& Sperber 2002: 45, Žegarac 2005: 4).

Autori konstatuju da teorija relevantnosti, između ostalog jeste i teorija ljudske komunikacije i spoznaje. Tako oformljena ona se zasniva na pretpostavci da ljudi imaju psihološku i biološku predispoziciju da obraćaju pažnju na demonstativne stimulanse (Žegarac 2005: 17). U tom smislu, relevantnost se može definisati i kao mera efikasnosti u ljudskoj spoznaji i komunikaciji (Žegarac 2005: 17).

Prema literaturi, teorija relevantnosti polazi od pretpostavke da je ljudski kognitivni sistem usmeren ka maksimalnoj relevantnosti, odnosno, ka postizanju največeg broja kognitivnih efekata uz najmanji utrošak procesualnog napora (Dansieh 2008; Sperber \& Wilson 1995). Ovo osnovno kognitivno usmerenje formulisano je kao prvi ili kognitivni princip relevantnosti (Sperber \& Wilson 1995: 260): „The first (cognitive) principle of relevance: Human cognitive processes are aimed at processing the most relevant information available in the most relevant way." (Ljudski kognitivni procesi usmereni su ka obradi najrelevantnije raspoložive informacije na najrelevantniji način. Prevod sa engleskog: Miloš D. Đurić \& Nada Krnjaić-Cekić).

U najkraćim crtama, u teorijskom okviru teorije relevantnosti, glavni predmet proučavanja su misli, koje su privatne i neiskustvene, i demonstrativni činovi, koji su javni i iskustveni, a kojima se misli saopštavaju. Kada se izvesna informacija saopštava, ona nameće slušateljki jezičke poruke ili čitateljki jezičkog materijala izvesno očekivanje relevantnosti. Preciznije, govornica zahteva pažnju sagovornice, inače komunikacija ne bi uopšte uspela. Na dalje, sagovornica dobija izvesne kognitivne efekte koji su vredni utroška procesualnog napora. Opisani proces je regulisan drugim ili komunikativnim principom relevantnosti (Sperber \& Wilson 1995: 260): „The second (communicative) principle of relevance: Every act of ostensive communication conveys a presumption of its own optimal relevance." (Svaki čin demonstrativne komunikacije saopštava pretpostavku o sopstvenoj optimalnoj relevantnosti. Prevod sa engleskog: $\mathrm{M}$. D. Đurić \& N. Krnjaić-Cekić).

Princip relevantnosti nameće određenu interpretativnu strategiju (Carston 1999: 8): „Consider possible cognitive effects in their order of accessibility (i.e. following a path of least effort)." (Razmatraj moguće kog- 
nitivne efekte prema redosledu njihove pristupačnosti (tj. prateći put najmanjeg napora) prevod: M. D. Đurić \& N. Krnjaić-Cekić). Karstonova kaže da je potrebno da se zaustavimo kada se postigne očekivani nivo relevantnosti, ali i onda kada izgleda neostvarljiv. Pogledaćemo primer iz našeg korpusa iz jednog našeg ranije korpusa naučnog registra, koji pripada oblasti fizike električnih gasnih pražnjenja, ali istovremeno prikladno ilustruje i primenu teorije relevantnosti na prevođenje konkretnog naučnog registra:

$X$ : Shall we consider the effects of long-range forces?

$\mathrm{Y}$ : The force of interaction is cut off at the Debye length.

Sagovornica X mora da uloži dodatni inferencijalni napor da bi razumela odgovor sagovornice $Y$. Istovremeno, međutim, ona dobija i dodatne efekte, a sve ovo može se ilustrovati shematski sledećim pragmatičkim procesima koje je Karstonova (Carston 2002: 140) modelovala prema Sperberu i Vilsonovoj (Wilson \& Sperber 2000):

(1.2)

(a) rečenica sagovornice $Y$ ima logičku formu [The force of interaction is cut off at the Debye length] (Ovo je autput jezičkog dekodiranja, odnosno, izlaz jezičkog dekodiranja).

(b) Iskaz sagovornice $\mathrm{Y}$ je optimalno relevantan za sagovornicu $\mathrm{X}$. (Ovo je pretpostavka o relevantnosti).

(c) Iskaz sagovornice $Y$ postaje relevantan time što odgovara na pitanje sagovornice $X$. (Ovo je standardno očekivanje relevantnosti kada se radi o pitanjima).

(d) Pri razmatanju efekata sila sa dejstvom na daljinu u teoriji sudara, može se pokazati da interakciona sila treba da se odseče na Debijevoj dužini. (Ovo je krajnje pristupačna pretpostavka kojom se pospešuje odgovor na pitanje sagovornice $X)$.

(e) Sila interakcije treba da se odseče na Debijevoj dužini tamo gde se razmatraju efekti sa dejstvom na daljinu. (prvo pristupačno obogaćenje iskaza sagovornice $Y$ koje može da se kombinuje sa (d) u odgovoru na pitanje sagovornice $X)$.

(f) $U$ teoriji sudara kod efekata sila sa dejstvom na daljinu (verovat- 
no) sila interakcije treba da se odseče na Debijevoj dužini. (Ovo je izvedeno iz (d) i (e), zadovoljava (c) i postaje implikatura iskaza sagovornice Y).

(g) Sila interakcije mora da se odseče na Debijevoj dužini, zato što bio bilo poželjno razmotriti efekte sa dejstvom na daljinu u teoriji sudara. (Ovo je vrlo pristupačna implikatura izvedena iz (d) i (e) koja zajedno sa (f) i drugim implikaturama zadovoljava (b), standardno očekivanje relevantnosti).

(h) Sagovornice X i Y mogu da sagledaju i nešto drugo. Mogu da uzmu u obzir debljinu graničnog sloja, koji se stvara između plazme i površine suda.

Kao što smo ilustrovali primerima (1.2a-1.2h), koji su modelovani prema pragmatičkim procesima Karstonove, saopštene propozicije se uzajamno paralelno podešavaju, te stoga inferencijalni proces ide od eksplikature ka implikaturi i obrnuto. Uloga pragmatičkog sistema je da dođe do značenja sagovornice $Y$, ili preciznije, do onoga što je sagovornica $Y$ nameravala. Ne manje relevantna uloga u ovom okviru jeste i uloga koju ima kontekst. Sperber i Vilsonova smatraju da se sagovornici pokušavaju da odaberu kontekst koji će maksimalno povećati relevantnost. Oni još preciznije konstatuju da se naročito u verbalnom razumevanju relevantnost tretira kao data, a kontekst se tretira kao promenjljiva (Sperber \& Wilson, 1995: 142).

U narednom delu pogledaćemo tri decenije razvoja Teorije relevantnosti.

\section{Tri decenije Teorije relevantnosti}

U ovom delu se osvrćemo na pregled razvoja teorije relevantnosti prema lingvističkoj literaturi koja je obrađivala razvoj ove teorije. Osvrćući se na prvu deceniju teorije relevantnosti, autori najpre daju uvid u osnovne postavke ove teorije, analizirajući situaciju nakon prve decenije, i komentarišući teoriju i njenu široku primenu u proučavanju komunikacije (Yus Ramos 1998: 305).

No, najpre pogledajmo razvoj pre formalnog početka teorije relevantnosti. Pojam „relevantnost“ se koristio u mnogim oblastima kog- 
nitivne nauke, uključujući logiku, veštačku inteligenciju i psihologije rasuđivanja (Wilson 1999: 719). Relevantnost, kao formalni termin, najpre se pominje u kontekstu konverzacione relevantnosti (Dascal 1977). Analizirajući maksime koje upravljaju komunikacijom, i koje se mogu koristiti da bi se generisale implikature, citirani autor posebno ističe Grajsovu maksimu „budite relevantni“ $(R)^{1}$, te je stoga i njegova studija nastala iz pokušaja da razjasni način na koji maksima R funkcioniše (Dascal 1977: 309). Na dalje, ovaj autor pravi distinkciju između dva tipa relevantnosti pragmatičke i semantičke. Pored toga, uvodi i različite podtipove.

Pored ovog autora, pre formalnog početka teorije relevantnosti, i jedna lingvistkinja operiše pojmom relevantnosti u svojoj studiji o pragmatičkim konektorima i principu relevantnosti (Brockway 1982). Kada govori o uspostavljanju relacija između iskaza i sistema verovanja govornice, ona govori o mnogostrukim mogućnostima interpretacije iskaza (Brockway 1982: 7). U literaturi se kaže da u svakodnevnom životu, u nauci i filozofiji, izražavamo često procene o relevantnosti. Prema citiranom autoru, činjenica $a$ je relevantna za činjenicu $b$, teorija $c$ je relevantna za delovanje $d$, iskaz e je irelevantan za verovanje $f$, itd. Dodaje se i da imamo poverenje u takve naše procene, pošto smo spremni da zasnivamo važne odluke na osnovu ovih procena (Dascal 1977: 309). U literaturi se iznosi sledeća pretpostavka: interpretacija jednog iskaza jeste funkcija njegove relacije prema verovanju slušateljke, a ovaj odnos može biti specifikovan bilo implicitno bilo eksplicitno (Brockway 1982: 11).

Formalni početak teorije relevantnosti, kao formalne teorije, započinje objavljivanjem monografije Relevance: Communication and Cognition Dana Sperbera i Deirdre Wilson 1986. godine. Upravo je, prema literaturi, najveća razlika između Grajsa i ovih autora u objašnjavanju komunikacije. Naime, dok Grajs objašnjava komunikaciju delimično, i polazi od razlike između eksplicitnog i implicitnog, dotle Sperber i Vilsonova posmataju komunikaciju kao celinu, eksplicitnu i implicitnu (Polovina 1996: 50).

U nastavku rada, pogledaćemo razvoj na osnovu pregleda dve značajne reference: Yus Ramos (1998) i Padilla Cruz (2016). Analizirajući deceniju teorije relevantnosti, prvi autor obezbeđuje uvid u teoriju relevantnosti Sperbera i Vilsonove, analizirajući situaciju nakon deset godina

1 Prevod ove maksime je preuzet iz literature (vidi: Žegarac 2005). 
od formalnog začetka teorije. $\mathrm{U}$ ovom radu on daje komentare u vezi sa teorijom i njenom širokom primenomu u izučavanju komunikaciije. Autor daje brojne i raznovrsne bibliografske izvore i nabraja različite domene primene. Na samom početku pregleda konstatuje da je teorija relevantnosti zapravo i duže od jedne decenije i nabraja i kritičare ove teorije (Yus Ramos 1998: 305). Ovaj autor daje pregled refernci koje su se bavile kontroverznim problemima u pragmatičkim istraživanjima kao što je to, između ostalog, uloga doslovnog značenja u shvatanju indirektnih iskaza. Zatim, nabraja autore koji se bave metaforom i metonimijom iz ugla teorije relevantnosti. Ističe i primenu ovog teorijskog okvira u domenu istraživanja učtivosti i strategija učtivosti (Yus Ramos 1998: 312).

$\mathrm{U}$ ovom deskriptivnom pregledu, smatramo najpertinentnijim autorov rafiniran pregled primena teorije relevantnosti. On eksplicitno kaže da se teorija relevantnosti uspešno primenjuje na različite tipove diskursa, a ove primene su dokaz važnosti teorije relevantnosti za savremena istraživanja jezika i komunikacije (Yus Ramos 1998: 327). U ovom razvoju, prvu primenu koju navodi jeste u gramatici i diskursu. Ovaj autor kaže da teorija relevantnosti ima široke implikacije za sintaksu, naročito ako sintaksičke obrasce rečenica interpretiramo da imaju važnu ulogu u kvalitetu ishoda procesovanja recipijenata. Ovo je slučaj, tim pre što logička forma iskaza mora biti obogaćena kako bi pružila propouzicione forme. Prema literaturi, primena teorije relevantnosti takođe vršena i u okviru kasnijih generativnih pristupa, kao što su pristup rekcije i veziavanja, ali i u okviru minimalizma (Yus Ramos 1998: 328).

$\mathrm{U}$ ovom razvoju značajno mesto pripada analizama koje se bave gramatičkim aspektima koji se često preklapaju sa semantičkim i pragmatičkim aspektima jezika. Ovaj autor kaže da, u okviru ovog teorijskog okvira, postoje dve vrste značenja koje presecaju mnoge lingvističke dihotomije raspoložive u pragmatičkom istraživanju, poput sledećih: opisivanje - impliciranje; konstatovanje - pokazivanje; kazivanje - konvencionalno impliciranje; istinosno-uslovljena - koja nije istinosno-uslovljena; reprezentaciona - komputaciona, itd. (Yus Ramos 1998: 328).

Ovaj autor u svom pregledu posebno ističe koncept zapreke u okviru teorije relevantnosti, sa primenom na diskursne konektive. Takođe u fokus dovodi i distinkciju, koja se ne može nikako zaobići u pregledu razvoja teorije relevantnosti, odnosno distinkciju između konceptualnog i pro- 
ceduralnog kodiranja. Istorijskim razvojem obuhvaćene su i druge oblasti gramatičkog interesovanja zasnovanog na teoriji relevantnosti, poput primene teorije relevantnosti na analizu rečeničnih kategorija i vrsta reči, primenu teorije relevantnosti na gramatički način. Ovaj teorijski okvir primenjen je i na diskursne partikule i rečenične priloge, glagolsko vreme i glagolski vid, modale i pomoćne glagole, zatim gramatiku teksta i diskursa (Yus Ramos 1998: 329).

$\mathrm{Na}$ dalje, tokom svoje prve decenije, teorija relevantnosti se koristila i za analizu izvesnih stilskih obeležja rečenica i teksta, kao što je uloga date/nove informacije. Pored toga, primenjena je na izučavanje elipse, kao i raznovrsne analize stila.

Ovaj autor posebno ističe primenu i razvoj teorije relevantnosti u domenu medijskog diskursa. Posebno je zanimljiva autorova primena ovog teorijskog aparata na interpretaciju verbalno-vizuelnog medijskog diskursa, u okviru koje je uspostavio egzaktan model zasnovan na matematičkoj kombinaciji četiri parametra koji su generisali šesnaest četvorostrukih kategorija (Yus Ramos 1998: 330). Zatim, nabraja primenu u oblasti književnosti, ističući autore koji su predložili izvestan broj nivoa ili slojeva u svakoj komunikativnoj interakciji. Posebno je obradio i primenu teorije relevantnosti u domenu prevođenja (o čemu će biti detaljnije reči u delu ovog rada posvećenog primeni teorije relevantnosti u teoriji i praksi prevođenja).

U razvoju je relevantno pomenuti i ulogu prediktabilnosti čija interpretacija je dosledna sa principom relevantnosti, odnosno ona koja obezbeđuje najveći broj kontekstualnih efekata u zamenu za procesualni napor. Upravo u ovako prikazanom okviru, autor opisuje razvoj studija koje se bave primenom teorije relevantnosti u izučavanju humora (Yus Ramos 1998: 332-333). Naravno, u ovom razvojnom putu, ne prenebregava se ni mogućnost primene teorije relevantnosti u oblastima kao što su obrazovanje i politički diskurs, no to izlazi iz domena lingvističkih proučavanja relevantnosti.

U svom sveobuhvatnom pregledu (za prvih deset godina teorije relevantnosti), citirani autor obezbeđuje i impozantan bibliografski aparat koji svedoči o tome da primena teorije relevantnosti na druge diskurse pruža sliku teorije Sperbera i Vilsonove koja ima veliku vitalnost i kontinuirani razvoj (Yus Ramos 1998: 333). U pomenutoj studiji, nabrojan je im- 
pozantan broj radova koji se bave najrazličitijim aspektima jezika, između ostalog, iz ugla teorije relevantnosti.

Druga konsultovana studija pruža pregled za tri decenije teorije relevantnosti. Autor najpre govori o revoluciji zasnovanoj na teoriji relevantnosti, zatim o važnim konceptima: intenciji, manifestnosti i kognitivnom okruženju (Padilla Cruz 2016: 3-4). Ovaj autor opisuje ovu teoriju kao teoriju zasnovanu na dva opšta principa, zatim u razvoj uključuje i pregled shvatanja podležnog ključnog termina. Posebna pažnja se posvećuje iskazima kao metareprezentacijama. Naime, autor konstatuje da iskazi imaju metarepretentacionu upotrebu pošto su iskazi reprezentacije reprezentacija (Padilla Cruz 2016: 10).

Sve ovo daje i novu sliku shvatanja. Naime, pošto dekodiranje pruža skup konceptualnih reprezentacija logičke forme, koja nije potpuno propozicionalna i potrebno joj je obogaćenje putem inferencije, inferencijalnoi obogaćenje se svodi na izvršavanje nekih zadataka i rezultira eksplikaturom iskaza (Padilla Cruz 2016: 11-12). Na dalje, u razvoju, citirani autor dovodi u žižu distinkciju između konceptualnog i proceduralnog kodiranja. Zatim, opisujući razvoj pragmatike zasnovane na teoriji relevantnosti, citirani autor pominje različite primene ovog teorijskog okvira, nadovezujući se na prethodne deskriptivne opise (vidi: Yus Ramos 1998), te u tom svetlu pominju se raznovrsne primene i implikacije na poimanje ironije, metafore, metonimije, partikule, adverbijale i skalarne implikature. Takođe, teorija relevantnosti je primenjivana i na temeljne analize konceptualno-proceduralne distinkcije, intonacije, pojave fokusa, semantičko poddeterminisne jezičke oblike i ulogu pragmatičke inferencije (Padilla Cruz 2016: 16). Pored toga, ovaj autor ističe i primenu teorije relevantnosti na književnu komunikaciju, medijski diskurs i humor, a neizostavno je pomenuti značajan obim istraživanja usmerenih ka gramatici i diskursu, koji obrađuju naročito probleme, poput: diskursnih markera, različitih vrsta rečeničnih priloga i partikula, glagolskog načina, modalnosti, glagolskog vremena i vida ili pak reformulacije. Pored toga, ovaj teorijski okvir je primenjen i na niz radova iz oblasti pragmatike eksplicitne komunikacije. Ovaj autor nabraja i primenu teorije relevantnosti i njen eksplanatorni potencijal na evidencijalnost, pratikule, humor, diskursne markere, trope, intonaciju i parajezik.

U odnosu na prethodni deskriptivni prikaz prve decenije razvoja teorije relevantnosti (Yus Ramos 1998), kod ovog autora nalazimo i pri- 
kaz primena teorije relevantnosti na nesporazum i pragmatički prekid, fatičku komunikaciju, (ne)učtivost, istorijsku lingvistiku, usvajanje jezika, pragmatičku kompetenciju, međujezički pragmatički razvoj, kompjuterski posredovanu komunikaciju, ekspresivno značenje, komunikacijske poremećaje i kliničku pragmatiku, odnos između epistemičke budnosti i shvatanja (Padilla Cruz 2016: 18). Imajući sve ovo u vidu, onda nije preterano mišljenje izneto u literaturi da se istraživanje iz perspektive teorije relevantnosti nastavlja sa produženim entuzijazmom i snažnim podsticajem (Padilla Cruz 2016: 17).

Ovde bi mogli pomenuti i kontrastivna istraživanja terminologije teorije relevantnosti. Neka terminološka rešenja u srpskom jeziku su ponuđena u studijama koje se bave osnovama teorije relevantnosti (Žegarac 2005), ali i u specijalizovanim glosarima (Đurić \& Krnjaić-Cekić 2006).

Nakon ovog kratkog istorijskog osvrta, zasnovanog na relevantnoj literaturi, u narednom odeljku pogledaćemo relevantnost i prevođenje.

\section{Teorija relevantnosti i prevođenje naučnog registra}

Odabrali teoriju relevantnosti kao teorijsko-metodološki okvir, pošto smo smatrali da teoriji i praksi prevođenja, ili konkretno prevođenja naučnog registra u našem slučaju, može da doprinese upravo kognitivnopragmatički pristup jeziku i prevođenju. U pertinentnoj literaturi se konstatuje da je do sada malo urađeno po pitanju mesta relevantnosti u prevođenju (Dansieh 2008: 234). Naše istraživanje je informisano sledećim studijama: Dansieh (2008), Gutt (1989), Gutt (2010), Martínez (1998), Rosales Sequeiros (2001). Kada smo evaluirali srpske prevodne ekvivalente obratili smo pažnju na efikasnost prevoda. Ovo je naročito bitno, pošto prevodilac sledi strategiju najmanjeg napora i princip relevantnosti, ali istovremeno vrši semantičke i pragmatičke odabire.

U literaturi je već više puta pominjana konceptualno-proceduralna dihotomija, pa onda ne iznenađuje da u primeni ove teorije na prevođenje, kažemo da jezičke oblike prevodimo na dve vrste kognitivnih podataka, a to su koncepti i procedure. U okviru prevođenja, uzeli smo u obzir ono što se navodi u literaturi, da konstituenti (tj. konceptualni izrazi) sačinjavaju semantičku reprezentaciju iskaza, a proceduralni izrazi pružaju podatke 
o načinu postupanja s konceptualnim reprezentacijama. Istovremeno, konceptualno-proceduralna dihotomija jezičke, odnosno u ovom slučaju, prevodne semantike čini se kao važna pretpostavka teorije relevantnosti naročito pošto je korisna za kognitivno-pragmatičku teoriju prevođenja.

Takođe je relevantan pragmatički prevod koji karakterišu različite konfiguracije eksplikatura i implikatura. Prema literaturi (Gutt 2010), eksplikatura prevoda treba da ima isto koliko i eksplikatura originala, a implikatura prevoda treba da ima isto koliko i implikatura originala. Primenjujući preporuke iz literature, posmatrali smo prevođenje naučnih i stručnih termina u svetlu principa relevantnosti Sperbera i Vilsonove (Frade 2015: 125-141). Naročito smo imali u vidu da

Ponekada se doslovno i konceptualno kodirano značenje modulira u stvarnoj upotrebi. Stoga, relevantna lingvistička literatura konstatuje javljanje suženja jezički specifikovanog značenja (Carston 2002). Oslanjajući se na literaturu teorije relevantnosti, ilustrovaćemo sužavanje primerima iz našeg korpusa:

Sagovornik X: "Shall we use the same superposition principle?"

Sagovornik Y: "The superposition principle could be used for the multi-mode regime and the complex laser beam intensity distribution."

Pitanje sagovornika $X$ generiše očekivanje relevantnosti da će sagovornik Y naposletku obezbediti odgovor. Leksički koncept SUPERPOSITION PRINCIPLE ima za cilj da se inferencijom dođe do specifično saopštenog koncepta SUPERPOSITION PRINCIPLE*. Ovaj koncept, koji je konstruisan ad hoc, može se dalje koristiti kako bi obezbedio relevantnu kontekstualnu premisu (If the multi-mode regime operates, then the superposition principle could be used), koja, bi zajedno sa iskazom sagovornika Y, garantovala inferencijalnu derivaciju sagovornika ne samo u pogledu impliciranog zaključka, već i nekih drugih saopštenih pretpostavki. Ovo ćemo ilustrovati shemom koju nalazimo u literaturi, a koju smo primenili na naš primer iz korpusa.

Eksplikatura: The same superposition principle* is used. Implicirana premisa: If one uses the same superposition principle*, 
it may be applied both in the context of multi-mode working regime and laser beam intensity distribution.

Neposredan impliciran zaključak: The superposition principle* could be used in multi-mode regime and laser beam intensity distribution.

Dalji implicirani zaklučak ${ }_{1}$ : The multi-mode working regime and the complex laser beam intensity distribution share the same superposition principle*.

Dalji implicirani zaključak $_{2}$ : In case of linear governing partial differential equation, the final solution could be presented as a superposition (or the sum of the partial differential equation solutions).

Dalji implicirani zaključak ${ }_{3}$ : This approach could be applied even when the incoming laser beam is not aligned with the axis of a cylindrical object.

Na osnovu upravo citiranog primera i ekscerpata iz našeg korpusa, konstatovali smo da su leksički i pragmatički procesi sužavanja jezički specifikovanog značenja ilustrovani leksičkim konceptom „superposition principle“, koji je aktiviran traženjem relevantnosti. Stoga nije iznenađujuće da ovaj koncept sledi inferencijalni put najmanjeg kognitivnog napora birajući najpristupačniji skup kontekstualnih premisa, najpristupačnije sužavanje kodiranih koncepata i najpristupačnije kontekstualne implikacije. Sve pomenuto obezbeđuje optimalno relevantnu interpretaciju za sagovornika X. Konačno, opisani proces se završava kada je očekivanje relevantnosti ispunjeno.

Prema literaturi (Carston 2002), konceptualno-semantički izrazi imaju svoje adresu u memoriji gde se pohranjuju različiti kodirani koncepti. Kao što se to konstatuje u okviru ovog teorijskog okvira, leksički unosak sadrži fonetske, fonološke i sintaksičke podatke, koji su ekvivalenti mentalnom leksikonu u teorijskom okviru generativne gramatike.

Sada ćemo ilustrovati pomenuti okvir (Carston 2002) na primerima iz našeg korpusa, koji bi bili ekvivalentni primerima koje pominje Karstonova. Pogledaćemo leksički ajtem gas plasma display.

Konceptualna adresa: gas plasma display

Denotacija: a set of displays 
Leksički ulaz: /gas plasma display/ a noun, etc.

Logički ulaz: a type of computer display

Enciklopedijski ulaz: a computer display that works on the same principle as a neon light; the display is usually orange on black. Gas plasma screens were used on early laptop computers. They are bright and easy to read, but they consume considerably more electricity than LCD displays.

That is so gas plasma display kind of thing.

Konceptualna adresa GAS PLASMA DISPLAY u ekscerptu (3.2) uvek se aktivira kada se čuje ili pročita jedinica gas plasma display. Ono što bi moglo biti korisno za teoriju i praksu prevođenja jeste premošćavanje jaza između kodiranog koncepta GAS PLASMA DISPLAY i koncepta GAS PLASMA DISPLAY* koji se saopštava u datom iskazu. Premošćavanje se vrši putem pragmatičke inferencije. Dakle, i ovde vidimo teoriju relevantnosti na delu prilikom interpretacije veoma važnih termina u naučnom registru, odnosno u diskursu elektrotehnike, računarstva i mašinstva.

lako teorija relevantnosti nije jedini teorijski okvir koji može imati važne implikacije za teoriju prevođenja i prevodilačku praksu, čini nam se da ona ipak obezbeđuje jedan kognitivno-zasnovano i pragmatički motivisano tumačenje u deskriptivnom i eksplanatornom smislu. Pogledaćemo jednu leksičku jedinicu iz našeg korpusa - executive system control. Analiziranjem pisanog i usmenog diskursa, koji sadrži ovu leksičku jedinicu, naišli smo na sledeće prevodne ekvivalente: upravljanje izvršnim sistemom, kontrolne informacije i komande sa parametrima koje se daju preko ulaznih uređaja.

Zatim smo pogledali leksičku jedinicu malfunction routine, a potom registrovali sledeće prevodne ekvivalente: modul za kvarove, rutina za pronalaženje kvara, program pomoću kojeg se otkriva koji je deo hardvera kompjutera neispravan ili kakva se vrsta greške javila u programu. Slično prethodnom primeru, master station u našem korpusu ima nekoliko prevodnih ekvivalenata: glavna stanica, matična stanica, jedinica koja upravlja terminalima na komunikacionoj liniji sa više stanica. Kao što se može primetiti u prethodno navedenim primerima, srpski prevodni ekviv- 
alenti su u većoj meri kodirani kada se uporede sa engleskim originalima. Ovo je verovatno slučaj, zato što prevodilica pretpostavlja da izvesne recipijentkinje ne poseduju dovoljno znanje i poznavanje datog domena nauke. Naravno, ovo nije izolovan slučaj, već se javlja u našem korpusu na više mesta. Međutim, prevodilice ipak pribegavaju odnosu u kome i kodirani i saopšteni koncepti podjednako dele sve analitičke i sintetičke implikacije, kako bi se izbegla potencijalno nenameravana tumačenja prevednog jezičkog materijala.

U narednom delu iznosimo zaključne napomene u vezi sa našim radom.

\section{Zaključne napomene}

Prilikom analiziranja korpusa prevedenih tekstova sa engleskog na srpski iz naučno-tehničkog registra (uglavnom elektrotehnika, računarstvo i mašinstvo), uočili smo raznovrsne semantičko-pragmatičke konfiguracije koje se ostvaruju u prijemu pisanog i usmenog diskursa. Odabrali smo kognitivno-pragmatičku teoriju relevantnosti, kao osnovni okvir, a smatrali smo da je nužno uključiti i pragmatiku u teoriju i praksu naučnog prevođenja. Pošto smo delovali u teorijskim okvirima teorije relevantnosti, ove konfiguracije se mogu shvatati kao kodno-inferencijalne konfiguracije. Čini nam se da ovakvo sagledavanje teorije i prakse prevođenja može u izvesnoj meri da doprinese izučavanju prevođenja naučnog registra.

U svojoj prevodilačkoj praksi susretali smo se sa velikim brojem modela i pristupa teoriji i praksi prevođenja, no učinila nam se kao najoptimalnija teorija relevantnosti. Ova teorija nam je omogućila izuzetno detaljno kognitivno-pragmatički profilisano objašnjenje u domenu teorije prevođenja i prevodilačke prakse, makar u deskriptivno-eksplanatornom smislu.

Analizom primera iz korpusa primetili smo da su direktni prevodi statistički relevantni kada su u pitanju tekstovi koji pripadaju naučnom registru. Ovakvi nalazi nisu iznenađujući, pošto se relevantnost direktnih prevoda u naučnom registru (elektrotehnici, računarstvu i mašinstvu, u našem slučaju), nalazi u maksimalnoj kodiranosti. Takođe, analizirajući primere iz korpusa, primetili smo da se kod naučnih tekstova i iskaza, skoro sasvim uvek, prati relevantnost izvornog teksta/iskaza. Ovde vredi pome- 
nuti da inače kod ove vrste diskursa nije relevantno generisanje slabih implikatura ili pak ličnih utisaka. No, primećeni su i slučajevi intervencije prevodioca u vidu povećane kodiranosti prevoda u odnosu na originalni tekst/iskaz, i to samo u slučajevima gde se pretpostavlja da recipijenti prevoda nešto ne poznaju u dovoljnoj meri. U ostalim slučajevima primećeo je da prilikom prevođenja naučnog registra, makar kada je u pitanju diskurs elektrotehnike, računarstva i mašinstva, kodirani koncepti dele sa saopštenim konceptima sve analitičke i sintetičke implikacije.

Smatramo da smo ilustrovali, makar u maloj meri, mogućnost primene teorije relevantnosti u prevođenju naučnog registra. No, svakako, naši nalazi su preliminarnog tipa i zahtevaju finije i detaljnije elaboracije.

\section{Literatura:}

Brockway, Diane. "Connecteurs pragmatiques et principe de pertinence." Langages, 16, No. 67, (1982) : 7-22. Print.

Carston, Robyn. Thoughts and Utterances, Oxford: Blackwell, 2002. Print.

Dascal, Marcelo. "Conversational relevance." Journal of Pragmatics, Vol. 1, (1977): 309328. Print.

Dansieh, Solomon Ali. "Relevance and Linguistic Markers: Implications for Translating from English into a Gur Language." Nordic Journal of African Studies, Vol. 17, Issue (4), (2008): 228-246. Print.

Đurić, Miloš D. \& Nada Krnjaić-Cekić. "Glosar teorije relevantnosti (srpsko-engleski)." PREVODILAC, XXXIII, 76, 3-4, (2016): 148-151. Print.

Frade, Celina. "Relevance and information processing in the design of specialized glossaries." Revista Linguistica - Revista do programa de pós-graduação em linguística da Universidade Federal do Rio de Janeiro, 11(2), (2015): 125-141. Print.

Gutt, Ernst-August. "Translation and relevance." UCL Working Papers in Linguistics, Vol. 1 (1989): 79-95. Print.

Gutt, Ernst-August. Translation and Relevance: Cognition and Context - Second Edition. London and New York: Cambridge University Press, 2010. Print.

Kordić, Snježana. „Konverzacijske implikature." Suvremena lingvistika, Vol. 17, (1991): 87-96.

Martínez, José Mateo. "Be Relevant (Relevance, Translation and Cross-Culture)." Revista Alicantina de Estudios Ingleses, Vol. 11 (1998): 171-182. Print.

Matthews, P. H. The Concise Oxford Dictionary of Linguistics. Oxford: Oxford University Press, 2005. Print.

Padilla Cruz, Manuel. "Three decades of Relevance theory." Relevance Theory: Recent 
Developments, Current Challenges and Future Directions. Ed. Manuel Padilla Cruz. Amsterdam: John Benjamins, 2016. 1-29. Print.

Polovina, Vesna. Prilozi za kognitivnu lingvistiku. Beograd: Filološki fakultet, 1996. Print. Rosales Sequeiros, Xosé. "Types and degrees of interpretative resemblance in translation." Revista Alicantina de Estudions Ingleses, Vol. 14 (2001): 197-211. Print.

Sperber, Dan \& Deirdre Wilson. Relevance: Communication and Cognition. Oxford: Blackwell, 1995. Print.

Sperber, Dan \& Deirdre Wilson. "Preface." Revista Alicantina de Estudios Ingleses, Vol. 11 (1998): v-vi. Print.

Wilson, Deirdre. "Relevance and Relevance Theory." MIT Encyclopedia of the Cognitive Sciences. Eds. R. Wilson \& F. Keil. Cambridge MA: MIT Press, 1999. 719-722. Print. Wilson, Deirdre \& Dan Sperber. "Truthfulness and Relevance." UCL Working Papers in Linguistics, Vol. 12, (2000): 215-257. Print.

Wilson, Deirdre \& Dan Sperber. "Relevance Theory: A Tutorial." Proceedings of the Third Tokyo Conference on Psycholinguistics. Ed. Y. Otsu. Tokyo: Hituzi Shobo, 2002. 4570. Print.

Yus Ramos, Francisco. "A decade of relevance theory." Journal of Pragmatics, Vol. 30, (1998): 305-345. Print.

Žegarac, Vladimir. Osnovi teorije relevantnosti. Beograd: Odsek za opštu lingvistiku, Filološki fakultet, Univerzitet u Beogradu, 2005. Print.

\author{
Miloš D. Đurić \\ Nada Krnjaić-Cekić
}

\title{
THREE DECADES OF RELEVANCE THEORY AND RELEVANCE-THEORETIC TRANSLATION OF SCIENTIFIC REGISTER
}

\section{Summary}

Our paper explores the application of Relevance Theory to the process of translation of scientific register. This register includes the oral and written data pertaining to electrical engineering, computer science and mechanical engineering discourses. The first part of the paper provides some introductory considerations about Relevance Theory. The second part is a descriptive exploration of three decades of Relevance Theory based on the pertinent linguistic literature. The third part of the paper is focussed on Relevance Theory and translation of concrete language material collected from the authors' translation practice. Corpus-based examples illustrate certain cases of lecical- 
pragmatic processes, when translators try to bridge the gap between the language material that is linguistically encoded and that which is actually communicated in the source language material. The fourth part provides our concluding remarks.

Key words: Relevance Theory, Scientific Register, Translational Equivalents, Discourse of Electrical Engineering, Computer Science and Mechanical Engineering, Lexical-Pragmatic Processes. 